\title{
TATA BUSANA ADAT BALI AGA DESA TENGANAN PAGRINGSINGAN DAN DESA ASAK KARANGASEM
}

\author{
I Ketut Darsana ${ }^{1}$ \\ Jurusan Pedalangan, Fakultas Seni Pertunjukan, \\ Institut Seni Indonesia Denpasar, Indonesia.
}

\begin{abstract}
This is a report of research findings regarding the lore of traditional clothing/costume in Bali Aga village in terms of its form, function, and meaning, along with its transformation in dance creativity. This is recently developed in the villages of Tenganan Pegringsingan and Asak Karangasem, where the art is inherited from one generation to another generation. The developed form of clothing in the traditional village of Bali Aga is distinctively unique, i.e. the featuring form is stimulated by the mutual support between the function and the meaning. In addition to featuring the aesthetic form, the clothing lore also reflects the meaning. This is possible due to the fact that the selected form does not only cater to the aesthetic deliberation, but he content reflects worthy and interesting symbolic values.
\end{abstract}

Keywords: Busana adat, Tenganan Pegringsingan, and Asak.

Tata Busana sebagai salah satu aspek yang sangat esensial dalam kehidupan manusia dan dapat memberikan wahana prilaku manusia untuk dapat menunjukkan jati dirinya. Dari busana tercermin suatu identitas diri sebagai manusia individual, manusia dari suatu negara dan manusia yang memiliki pranata sosial yang lebih tinggi. Keanekaragaman dalam tata busana adat di Indonesia tetap merupakan satu kesatuan budaya yang dikokohkan oleh adanya kesatuan bahasa dan agama.

Tata busana adat Bali tidak dapat dilepaskan dari kehidupan manusianya karena dia berkembang sejalan dengan dinamika manusia dan kebudayaannya. Ini berarti perubahan aspek sosial budaya yang sangat cepat akan mempengaruhi pula norma-norma dan tata busana adat yang berlaku di masyarakat. Tetapi meskipun sesuatu adat istiadat mengalami perubahan dan perkembangan, di dalamnya akan tetap kita jumpai unsur-unsur yang konstan. Unsur-unsur yang konstan, tetap memelihara kesinambungan atau kontinuitas antara masa lampau dan sekarang, antara sekarang dan yang akan datang. Andaikata unsur-unsur yang konstan ini tidak ada, maka sudah tentu 
generasi sekarang tidak perlu dan tidak akan dapat mengerti generasi yang mendahuluinya

Adanya proses globalisasi, informasi serta pesatnya perkembangan industri pariwisata, menyebabkan masyarakat Bali tidak lepas dari pengaruhpengaruh kebudayaan luar. Pengaruh kebudayaan luar tersebut akan membawa perubahan-perubahan yang mendasar dalam berbagai kehidupan masyarakat Bali. Termasuk juga di dalam tata busana adat Bali. Industri pariwisata telah memberikan dampak terhadap kebudayaan Bali dalam katagori positif dan negatif. Secara positif, masyarakat Bali memperoleh manfaat ekonomi serta kebudayaan Bali dirangsang secara lebih progresif. Secara negatif unsur-unsur kebudayaan tertentu untuk konsumsi wisatawan terlibat ke produksi masa, komersialisasi dan orientasi materialisme. Oleh karena itu antisipasi terhadap pengaruh negatif seperti tersebut di atas perlu lebih dini dipikirkan, karena tidak diinginkan timbulnya suatu generasi kita sampai tercabut dari akar budaya dan tata nilai budaya Bali. Usaha yang kongkret yang dapat dilakukan adalah dengan penggalian, pengkajian, pendalaman serta memahami norma-norma, adat istiadat termasuk juga tata busana adat yang diwariskan dalam masyarakat Bali.

Begitu pula halnya dalam tari Bali pada mulanya penari memakai busana atau pakaian sesuai dengan apa yang ada pada saat itu sedang dipakai. Perkembangan selanjutnya, sesuai dengan kedudukannya sebagai salah satu unsur dalam tari, maka pakaian atau busananya diatur dan ditata sesuai dengan kebutuhan tari tersebut. Busana (kostum) untuk tari-tarian tradisional memang harus dipertahankan. Namun demikian, apabila ada bagian-bagiannya yang kurang menguntungkan dari segi pertunjukan, harus ada pemikiran lebih lanjut. Pada prinsipnya busana (kostum) tersebut harus enak dipakai, tidak meng-ganggu gerak tari, menarik dan sedap dilihat penonton. Bila perlu murah harganya dan mudah didapat. Pada tata busana tari-tarian tradisional yang harus dipertahankan adalah desain dan warna simbolisnya. Secara umum hanya warna-warna tertentu saja yang bersifat teatrikal dan mempunyai sentuhan emosional tertentu pula. Di Indonesia pada umumnya merah memiliki arti simbolis berani, agresif atau aktif. Biru memiliki kesan teatrikal tentram. Hitam memberi kesan kebijaksanaan. Warna teatrikal lainnya adalah kuning yang memiliki kesan penuh kegembiraan dan putih memiliki kesan muda atau suci. Sekarang ini para koreografer mulai mencoba membuat desain busana (kostum) tari yang bukan saja berasal dari wayang kulit Bali dan drama tari yang lain, melainkan juga diambil dari busana tradisional "Bali Aga".

Selain beberapa hal yang sudah diutarakan di atas, tata busana dalam seni pertunjukan juga berguna untuk mempertegas fungsi dramatik atau fungsi ekspresif dari setiap peran. Fungsi ekspresif ini terlihat dalam penggambaran rasa sedih, ungkapan kemarahan dan lain-lain yang terkait dengan memainkan bagian-bagian tertentu dari tata busana yang dipakai oleh 
peran bersangkutan. Sementara diketahui penulis, tulisan-tulisan tentang busana adat Bali baru sebatas busana pengantin adat Bali dengan klasifikasi nista, madya, dan utama, serta busana Pitra Yadnya.

\section{BUSANA}

Seperti halnya suku-suku lain di Nusantara, Bali juga memiliki busana adat khas yang tampil mempesona dengan berbagai ragamnya. Kalau direkareka pengelompokannya, setidaknya ada kelompok busana adat Bali yang dikenal hingga kini, yaitu busana agung, busana adat re-resona, dan busana modern. Ketiga jenis busana adat ini masing-masing memiliki konsep dan fungsi tersendiri. Artinya satu jenis busana adat dipakai pada acara tertentu saja. Diluar itu busana adat bersangkutan tidak lazim digunakan. Lihatlah misalnya busana adat pendeta atau pemangku yang hanya dipakai pada saat hari-hari tertentu saja. Demikian pula pakaian khas remaja pada saat "Potong Gigi", dan juga pakaian tari Sanghyang, hanya dipakai pada saat tertentu saja.

Busana Agung merupakan busana tradisional Bali yang paling mewah. Busana ini terlihat gemerlap bak pakaian seorang raja beserta permaisurinya yang cantik dan anggun. Busana agung di Bali bentuknya juga beragam tergantung dari daerah dimana busana adat itu berada. Antara satu daerah dengan daerah lainnya di Bali memiliki kesamaan dan juga perbedaan dalam hal Busana agung ini. Namun untuk lebih mudah mengenali Busana Agung sebaiknya dilihat pada Busana agung yang paling umum digunakan. Busana jenis ini umumnya dipergunakan dalam rangkaian upacara "Potong Gigi" dan Perkawinan.Saat persembahyangan di halaman rumah untuk memohon keselamatan kehadapan Hyang Widhi sampai naik ke balai-balai tempat Potong Gigi berlangsung para remaja yang akan mengenakan busana jenis ini. Busana ini juga masih tetap digunakan tatkala upacara merajah menulisi dengan huruf sakti pada tempat-tempat tertentu di badan dan ke enam gigi yang akan diasah, mabiakala, natab ayaban, mapadampel, serta saat mejayajaya mohon keselamatan dan kesejahteraan.

Dalam rangkaian upacara perkawinan atau pawiwahan, Busana Agung dikenakan kedua mempelai sejak upacara pekala-kalaan di halaman sanggah atau merajan keluarga, saat natab ayaban, mejaya-jaya di balai-balai khusus yang dikenal dengan balai gede atau bale singasari dipimpin oleh seorang pendeta, upacara mejejauman kunjungan pihak keluarga pria bersama kedua mempelai ke keluarga pihak wanita, sebagai akhir rangkaian upacara perkawinan menurut adat Bali.

Sekali lagi Busana Agung memang beragam sesuai dengan desa-kalapatra (tempat, waktu, dan keadaan) setempat. Kain yang digunakan adalah wastra-wali khusus untuk upacara. Kadangkala juga bisa diganti dengan wastra putih, simbol penggerak kesucian. Yang paling umum wastra- wali 
seringkali diganti dengan kain songket, karena kain jenis ini sangat pas untuk mewakili kemewahan dengan gemerlap benangnya. Bagaimana pun kain jenis ini melambangkan status atau prestise bagi pemakainya. Selain mengenakan wastra kain sang pria juga menggunakan kampuh gelagan atau dodot yang ukurannya sama dengan kain yang dipakai. Kampuh ini juga dipakai hingga menutupi dada, karena si pria tidak mengenakan baju. Pada punggung seringkali tersembul keris yang rebah ke kanan. Biasanya keris yang disungkit adalah keris pusaka keluarga yang berhulu emas bertahtakan permata atau berbilah gading bagi yang punya. Hiasan kepala yang digunakan berupa petitis atau gelungan terbuat dari emas, dengan beberapa bunga emas, dan bunga segar yang bertengger di bagian belakang.

Adakalanya gelungan diganti dengan ikat kepala biasa atau sering disebut destar terbuat dari kain songket yang tidak kalah gemerlapnya. Langkah yang gagah, memegang ujung kain yang menjuntai panjang ke bawah, memberi nilai tambah bagi kelelakian seseorang di kala upacara berlangsung.

Bagi wanitanya, yang paling menarik untuk ditatap tentu hiasan kepalanya yang berupa petitis emas, ron-ronan yang dihias dengan rangkaian bunga cempaka di bagian belakang dikombinasikan dengan bunga kembang sepatu berwarna merah yang lazim disebut pucuk bang atau pucuk rejuna yang dipasang di tengah bagian muka gelung agung. Kembang sepatu ini bisa diganti dengan mawar merah atau bunga kenyeri susun merah yang tetap mengesankan meriah dan anggunnya paras sang wanita. Di lain tempat gelung agung biasa diganti dengan bancangan bunga tanpa petitis, dan ronronan.

Namun hiasan bunganya tetap sama, termasuk peran bunga emas yang sering mendominasi. Unsur lainnya adalah kain berwarna gelap yang disebut wastra wali cokordi, wastra wali keeling, atau wastra wali bias membah. Sebelum kain yang khusus ini dikenakan, wanita yang berbusana agung mengenakan terlebih dahulu kain lapis dalam yang disebut sinjang atau tapih yang nampak keluar dari batas bawah kain, yang ujungnya mengarah ke belakang, terlepas bebas diantara kedua kaki sang wanita.

Sinjang ini pada akhirnya seolah mengatur langkah wanita menjadi pelan namun anggun. Stagen atau pepetet juga dikenakan, dengan ciri khas terdiri dari potongan kain warna-warni yang indah dan harmonis ditambah dengan lukisan prada emas. Yang terakhir adalah peran selendang yang disebut wastra wali petak sari atau wastra wali kesetan gedebong dengan warna kuning sekaligus berfungsi sebagai penutup dada, dengan ujungnya menggelantung bebas ke belakang, melalui bahu kiri.

Busana Adat Reresonan adalah busana untuk bekerja dalam segala macam kegiatan adat. Karena itu, busana jenis ini ditata ringkas dan sederhana baik bagi wanita maupun prianya. Pada dasarnya baik wanita ataupun prianya hanya memakai kain serta penutup dada. Khusus untuk 
prianya, penutup dada disebut saput atau kampuh bisa langsung menjadi ikat pinggang, dan dinamai bebed, atau ubed-ubed. Kadangkala saput dipakai dengan ikat pinggang yang disebut sabuk tubuan seperti dikenakan remaja desa adat Tenganan Pegringsingan. Mereka menyebutnya saput mebasabasa. Kini baik wanita maupun pria melengkapi dirinya dengan baju, saat mengenakan busana adat reresonan

Busana Adat Modern, busana adat ini banyak memunculkan kreasikreasi baru, namun tetap memakai pola dasar tradisional. Bagi wanita mengenakan baju kebaya, selendang yang dijadikan stagen, serta kain. Sanggul wanita tetap dipilih sanggul tradisional Bali. Sedangkan untuk remaja lebih sering tidak mengenakan sanggul. Yang terpenting pada penggunaan busana jenis ini adalah pemilihan warna yang serasi antara kain, baju, selendang, serta aksesoris yang dikenakan. Bagi pria busananya terdiri dari destar atau ikat kepala, baju, kain, kampuh yang menyelimuti kain, umpal yang mengikat kampuh. Busana jenis ini sangat umum dipakai saat ini.

Pada setiap pelaksanaan PKB dari tahun ke tahun salah satu kegiatan yang terus ada adalah Pawai Pakaian Adat Bali baik yang digunakan dalam pelaksanaan Upacara Pitra Yadnya, Manusa Yadnya, maupun Dewa Yadnya. Penggunaan pakaian adat ini seringkali dilengkapi dengan berbagai macam sanggul atau pengikat kepala. Salah satu model ikat kepala wanita Bali yang sering kita jumpai di PKB adalah lelunakan. Mengurai rambut merupakan hal yang tidak lazim bagi wanita Bali apalagi pada kegiatankegiatan yang terkait dengan kegiatan adat. Pada zaman dulu, rambut terurai bagi wanita Bali hanya berlaku saat di peraduan, saat bersedih, atau melaksanakan sumpah tertentu. Di luar hal tersebut rambut wanita Bali mesti disanggul.

Dalam keseharian, untuk menghindari terlepasnya sanggul, wanita Bali akan mengenakan pengikat sanggul yang lazim disebut "teng kuluk". Di tempat umum seperti pasar-pasar tradisional, tengkuluk sangat lazim digunakan oleh masyarakat. Jenis dan bentuk tengkuluk pun sangat beragam. Salah satu diantaranya ya lelunakan. Lelunakan sendiri merupakan pengembangan tengkuluk dalam bentuknya yang manis dan indah, karena kain yang dipakai bukan lagi handuk, melainkan selendang. Kain selendang yang digunakan untuk lelunakan ujung-ujungnya tertata rapi serta memiliki bukaan yang lebar, sehingga lebih melindungi kepala dan mengikat rambut yang tergelung lebih erat.

Lelunakan yang menambah ayunya wanita Bali ini, pada awalnya merupakan pengikat kepala dan rambut wanita Desa Adat Badung. Dalam perkembangannya, cenderung menjadi milik khas wanita seluruh Kabupaten Badung. Bahkan karena keindahannya, sekarang telah menjadi milik wanita Bali, secara keseluruhan. Lelunakan biasanya digunakan dalam upacara kematian di banjar yang dikenal dengan Ngaben, dengan aneka 
rangkaiannya. Lelunakan menjadi semakin populer saat diciptakannya tari Tenun sekitar 1960-an. Si penari Tenun yang tentunya para remaja pilihan berparas ayu tampil di pentas dengan gelung lelunakannya yang dimodifikasi begitu indah dan asrinya. Maka jadilah lelunakan ini hiasan kepala wanita Bali yang memikat dan semakin popular, bahkan sudah pula dipakai pada acara resmi diluar kegiatan adat.

Perlu diketahui bancangan merupakan alat untuk menancapkan bunga. Disamping menghias kepala wanita, bancangan dipergunakan pula untuk menghiasi beberapa jenis sesajen atau sarana pemujaan lainnya, seperti gebogan, prani, gegaluh, pratima, pralingga, dan pecanangan saat upacara keagamaan. Tangkainya bancangan umumnya terbuat dari bambu sedangkan tempat menancapkan bunga terbuat dari kawat yang dibentuk seperti spiral, sehingga bunga yang tertancap bisa bergerak gemulai kala dipakai.

Sebagai bagian dari busana wanita Bali, bancangan umum dipakai dalam Tari Pendet, Tari Sisia, atau saat prosesi yang dinamai peed dilakukan. Dalam momen seperti itu, bancangan merupakan bagian yang tidak terpisahkan dalam suatu mahkota kebesaran atau gelung-agung.

Kerangka Bancangan terbuat dari rotan kecil yang kalau di Bali disebut penyalin. Tempat menancapkan bunga diatur sedemikian rupa yakni mengecil ke atas. Namun bentuk keseluruhannya tetap berbentuk bulan sabit, atau Ardha Chandra seperti yang terlihat pada gelung agung gelung janger, onggar-onggar rejang Bungaya dan Rejang Asak. Warna bunga jepun Bali yang dipakai adalah yang berwarna putih dengan pangkal helai bunga berwarna kuning. Bunga ini selanjutnya diimbuhi kembang kuning Alamanda di bagian bawahnya, denga tajuk mahkota digunting sehingga selaras proporsi dan komposisinya dengan bunga jepun.

Satu lagi, di puncak tengah bancangan dipasang sekuntum bunga mawar merah atau sekuntum pucuk bang kembang sepatu warna merah yang juga disebut pucuk rejuna. Dengan gradasi dan komposisi warna yang manis dan indah itu, bancangan jepun sampai sekarang menjadi salah satu mahkota wanita Bali yang sangat popular.

Onggar-onggar entah kapan diciptakan, dan entah siapa penciptanya, hiasan kepala seunik dan seindah Onggar-onggar menjadi ada dan acapkali digunakan pada suatu acara di desa adat. Onggar-onggar merupakan gelung hiasan kepala di desa adat Bungaya Karangasem. Hiasan kepala ini dipakai para wanita penari Rejang Saput Karah. Gelung Onggar-onggar diselipi bunga emas yang disebut sekar sasak. Sehingga mahkota rejang itu membuat sang penari tampak semakin anggun.

\section{Pelestarian dan Perubahan}

Konsep, unsur dan struktur tata busana adat Bali, Kalau disimak seperti halnya sejarah perkembangan busana sejak dibutuhkan oleh manusia, 
ia merupakan salah satu unsur kebudayaan produk manusia Bali. Selaras dengan eksistensi kebudayaan Bali, yang hidup dan berkembang, sejak era tradisi kecil sampai era tradisi besar, tampaknya berkembang terus maju. Lebih-lebih pada era sekarang, era gemuruhnya ilmu komunikasi dengan produk peralatan teknologi modern yang didukung oleh sumber daya manusia Bali yang baik, kebudayaan Bali pada umumnya dan tata busana adat tampak semakin maju dan berkembang terus. Tetapi dalam mengantisipasi perkembangan kebudayaan Bali pada umumnya, dan keanekaragaman tata busana adat Bali Aga sebagai kekayaan budaya, perlu dipersiapkan jurus-jurus yang berupa perencanaan untuk menjaga keajengan dan kelestariannya. Sistem dan upaya yang patut ditempuh adalah dengan lebih diintensifkan lagi kegiatan-kegiatan inventarisasi, studi melalui penelitian dan seminar, untuk mengkaji, menganalisis seluruh hasil inventarisasi keanekaragaman tata busana adat Bali Aga sebagai kekayaan budaya. Kita jangan terlena dan keenakan untuk menjual warisan adihiluhung keanekaragaman tata busana adat Bali Aga sebagai kekayaan budaya, yang sekaligus sebagai salah satu aset pariwisata Budaya yang dikembangkan dan dipromosikan di Bali ini. Oleh karena itu terhadap kelestarian, pembinaan dan pembangunan keanekaragaman tata busana adat Bali Aga sebagai kekayaan budaya, menjadi tanggung jawab kita bersama untuk menanganinya. Lebih-lebih bagi mereka yang sebagai pewaris seluruh produk budaya, keanekaragaman tata busana adat Bali Aga. Andaikata upaya dan usaha itu dapat dilaksanakan kita telah dapat mewujudkan rasa tanggung jawab terhadap dua komponen yakni:

- Komponen yang merintis menciptakan melalui cipta, karsa dan kreativitas seluruh bentuk dan jeni serta keanekaragaman tata busana adat Bali sebagai kekayaan dan warisan budaya kepada kita yang hidup pada era sekarang.

- Komponen yang menjadi generasi mendatang, sebagai pewaris dan penerus eksistensi, kehidupan dan perkembangan keanekaragaman tata busana adat Bali sebagai kekayaan budaya yang adhiluhung, yang memiliki nilai-nilai luhur dan spritual, seperti yang telah dikemukakan dalam sub-sub sejarah perkembangan tata busana adat Bali, walupun dikemukakan secara pantheon dan mitologis, pada dasarnya kalau kita berpijak dan meniti kepada sumber itu, dapat dikemukakan tata busana adat bali, adalah meniru tata busana para Dewa. Untuk dapat membuktikan konsep ini, dapat disimak kembali konsep, unsur dan struktur busana arca-arca Istadewata atau pun wayang, serta Lontar Panji Amalat rasmi. Atau simak kembali konsep, unsur dan struktur busana agung adat Bali. Selain dari-pada itu, kalau upaya ini betul-betul dapat diusahakan untuk melaksanakannya, tidak akan terjadi the missing link, dalam eksistensi, kehidupan, pembinaan dan pengembangan kebudayaan Bali pada umumnya dan keanekaragaman tata busana adat Bali sebagai 
kekayaan budaya Bali, yang merupakan unsur dan Khazanah kebudayaan Nasional. Inventarisasi, pencatatan keanekaragaman tata busana adat Bali sebagai kekayaan budaya, patut diusahakan. Inventarisasi itu dapat diformulasikan persamaan konsep, unsur dan strukturnya, termasuk perbedaan dan ciri kekhasan masing-masing. Termasuk di desa-desa adat yang memiliki kekhasan tersendiri, seperti busana adat Desa Adat Tenganan Pegeringsingan, busana adat Daa dan Trunanya dalam berbagai kegiatan agama dan adat di lingkungan desa adatnya. Termasuk busana adat pada waktu Mabuang, magere Pandan. Dan juga khusus bagi daanya, pada saat ngerejang. Usaha yang sama patut juga dilakukan di Desa Adat Bungaya yang terkenal dengan Rejang Onggar-onggarnya, di Desa adat Asak, dengan Rejang Asaknya. Termasuk di Desa Adat Ngis yang terkenal dengan busana adat Daa Malongnya. Belum lagi di daerah Kabupaten yang lainnya, yang ada saja memiliki keunikan produk busana adatnya, seperti busana adat Deeng Gede dan Deeng Matah di beberapa Desa Adat di Kabupaten Buleleng.

\section{Faktor-faktor Yang Mendukung Pelestarian}

Kata faktor mengandung pengertian sesuatu hal (keadaan, peristiwa dan sebagainya yang ikut menyebabkan (mempengaruhi) terjadinya sesuatu. Sedangkan kata pelestarian berasal dari bahasa Jawa, yang menjadi perbendaharaan kata bahasa Indonesia. Kata pelestarian berasal dari kata lestari yang berarti tetap selama-lamanya tidak berubah sebagai sediakala, sehingga kata pelestarian mengandung pengertian menjadikan (membiarkan) tetap tidak berubah. (Purwadarminta, 1976:592). Dengan demikian pengertian faktor yang mendukung pelestarian, mengandung pengertian sesuatu yang membantu mendukung sesuatu menjadi tetap selama-lamanya tidak berubah sebagai sediakala.

Sesungguhnya berdasarkan pengertian di atas, ada beberapa faktor yang memiliki andil dalam usaha pelestarian tata busana adat Bali Aga, antara lain faktor agama, faktor adat, faktor sikap, yang dalam hal ini mengacu kepada masyarakat selaku pemanfaatan atau pemakai tata busana adat Bali Aga. Faktor sikap ini mengandung pengertian suatu usaha yang berdasarkan pendirian atau pendapat masyarakat, kelompok-kelompok, lembaga-lembaga yang ada dalam masyarakat, diharapkan dapat melestarikan tata busana adat Bali Aga. Maksudnya tindakan-tindakan atau usaha-usaha apa saja yang dilakukan oleh kelompok-kelompok, lembagalembaga baik resmi maupun tidak resmi yang diharapkan dapat melestarikan tata busana adat Bali Aga.

Desa adat memegang peranan penting dalam usaha pelestarian tata busana adat Bali Aga. Hal ini tampak dalam aktifitas yang dilakukannya baik yang bersekala besar atau luas, selalu tampak mengenakan tata busana adat Bali Aga. Tata busana adat Bali Aga yang digunakan sudah tentunya 
disesuaikan dengan situasi. Dengan menggunakan tata busana adat Bali Aga dalam aktifitasnya, ini berarti lembaga Desa Adat telah melakukan suatu usaha agar tata busana adat Bali Aga menjadi tetap kekal atau tetap selamalamanya tidak berubah sebagai sediakala.

Penggunaan tata busana adat Bali Aga khususnya tata busana Dehe dan Truna di desa Tenganan Pagringsingan digunakan dalam upacara yadnya, yang dalam hal ini adalah upacara DewaYadnya (Rejang) dan Manusa Yadnya (Pernikahan).

Lembaga-lembaga resmi seperti Pemerintah Daerah Bali, baik Tingkat Propinsi, Tingkat Kabupaten, maupun Tingkat Kecamatan, juga acapkali mengadakan usaha pelestarian tata busana adat Bali, yang dilaksanakan dengan cara melalui instruksi-instruksi dengan surat keputusan, dan caracara lainnya yang dianggap wajar. Usaha pelestarian busana adat Bali Aga sering kita temukan dalam rangka PKB.

Kiranya dengan seluruh uraian ini telah cukup dapat dikatahui bahwa faktor sikap masyarakat adalah merupakan sumber usaha pelestarian tata busana adat Bali. Berlandaskan pada faktor sikap inilah usaha-usaha pelestarian tata busana adat Bali dituangkan dalam faktor agama dan adat, yang pelaksanaan pelestariannnya, melalui berbagai cara, antara lain melalui pembinaan-pembinaan, dan juga melalui upacara-upacara yang bersifat keagamaan.

\section{Faktor-Faktor yang Membawa Perubahan.}

Usaha pembangunan telah menghadapkan kita secara langsung dengan masalah budaya dan dengan proses budaya kita memperbaharui diri dalam menjawab tantangan-tantangan kehidupan baru. Kebudayaan merupakan kerangka sandarannnya, sistem pengetahuan yang merupakan aturan-aturan, petunjuk-petunjuk, rencana-rencana yang terdiri atas serangkaian model kognitif yang digunakan secara seliktif oleh manusia yang memilikinya sesuai dengan lingkungan yang dihadapinya dengan mempergunakan segala kemampuannnya untuk berjuang dan dengan demikian memperoleh kemajuan serta meningkatkan mutu hidupnya.

Tata busana adat Bali Age sebagai salah satu unsur kebudayaan, perwujudannya tidak lepas dari rangkaian pesan yang hendak disampaikan kepada anggota masyarakat lewat lambang yang dikenal dalam tradisi masyarakatnya. Berkenaan dengan pesan-pesan nilai budaya yang disampaikan, maka pemahamannya dapat dilakukan melalui berbagai simbol-simbol dalam ragam tata busana adat Bali Aga.

Dalam pengertian budaya bisa termasuk tradisi dan tradisi dapat diterjemahkan dengan pewarisan atau penerusan norma, adat istiadat, kaidah-kaidah tetapi tradisi tersebut bukanlah suatu yang tak dapat diubah, tradisi justru dipadukan dengan aneka ragam perbuatan dan diangkat dalam keseluruhannya. Mereka membuat tradisi, menerima, menolaknya atau 
mengubahnya. Itulah sebabnya mengapa kebudayaan merupakan cerita tentang perubahan-perubahan serta riwayat yang selalu memberi wujud baru kepada pola-pola kebudayaan yang sudah ada.

Pakaian sebagai hasil dari kerajinan tenun dari Bali sering disebut dengan kain Bali adalah salah satu diantaranya. Kerajinan tenun tersebut baik berupa kain maupun perhiasan penuh dengan hiasan dengan dekoratif yang indah, dengan desain yang indah komposisi yang harmonis serta bentuk ragam hiasnya yang mempunyai karakteristik yang mencolok. Demikian pula dengan teknik-teknik menghiasnya sangat berpariasi misalnya dalam pembuatan desain, cara menenun, pemakaian warna, bahan corak yang dapat menimbulkan kekaguman, sehelai kain tidak hanya berfungsi sebagai penutup tubuh belaka, akan tetapi merupakan hasil karya seni yang mengekspresikan si pembuat dengan masyarakatnya.

Dalam masyarakat Bali seluruh hidupnya dapat dikatakan serba dikelilingi oleh adat istiadat. Tegasnya kehidupan sehari-hari mereka tidak dapat dipisahkan dengan kehidupan adat-istiadatnya. Namun perlu juga disadari bahwa adat istiadat (penggunaan tata busana adat Bali) tidak lepas dari perubahan dan perkembangan baik cepat maupun lambat, namun demikian didalamnya akan tetap kita jumpai unsur-unsur yang konstan.

Dilihat dari sikap mental penggunaan busana Deha dan Truna desa Tenganan Pagringsingan maupun di desa Asak sudah mencerminkan tata krama. Secara dinamis tata busana adat Bali telah mengikuti perkembangan peradaban, dalam hal ini menitikberatkan pada sistem nilai keseimbangan dan keselarasan terutama dalam menumbuhkan rasa kesetiaan.

Nilai budaya Bali khususnya tata busana adat Bali Aga tidak mengalami perubahan. Dengan dimikian kelestarian perlu dijaga. Apabila kurang kepedulian terhadap permasalahan ini, maka dalam kurun waktu yang tidak lama akan mengakibatkan lunturnya jati diri nilai-nilai tata busana adat Bali Aga.

Untuk itu patutlah pembinaan dan bimbingan tetap dilakukan da-lam rangka melestarikan nilai-nilai budaya khususnya nilai budaya tata busana adat Bali Aga , Desa Adat adalah pengemban tugas utama, karena pendukung kebudayaan Bali adalah masyarakat Bali sendiri. Hal ini dapat dipahami, bahwa kedudukan, fungsi dan peran Desa Adat adalah merupakan ujung tombak dalam melestarikan nilai-nilai budaya dan sekaligus menjadi benteng pertahanan dalam menghadapi hal-hal yang tidak sesuai dengan jiwa dan kepribadian masyarakat Bali.

\section{SIMPULAN}

Fungsi Busana Teruna dan Daha desa Adat Tenganan Pegring-singan adalah untuk upacara Dewa Yadnya dan Manusa Yadnya serta sebagai sarana pengikat rasa solidritas masyarakat. Makna Busana Teruna dan Daha 
desa Adat Tenganan Pegringsingan adalah untuk menolak bala dan pengikat gejolak jiwa pemuda yang kondisi labil.

Bentuk Busana Teruna dan Daha Asak Karangasem terdiri dari bagian kepala, badan dan kaki. Bagian kepala berupa pusung lungguh yang terbuat dari $d u k$ atau ijuk, bunga empak-empak, blengker, bunga sandat, bunga mawar merah, bunga angle, perkapat, subang, pacek atau cucuk, jamang (dalam payas agung). Payas madya hanya menggunakan blengker, bunga kamboja Bali/Jepun Bali berbentuk setengah lingkaran. Bagian badan berupa sabuk klip, dua selendang prada, gelang tangan. Bagian kaki memakai tapih, dan kamen songket. Bentuk busana Teruna juga terdiri dari bagian kepala, badan dan kaki. Bagian kepala berupa udeng atau destar songket. Bagian badan memakai saput, umpal, keris, gelang tangan. Bagian kaki memakai wastra songket.

Transformasi busana Teruna dan Daha desa adat Tenganan Pegringsingan dan desa adat Asak Karangasem dalam tata busana seni tari pada Tugas Akhir Mahasiswa Jurusan Seni Tari ISI Denpasar dapat dilihat pada: elemen warna, busana untuk tubuh dan hiasan untuk kepala.

\section{DAFTAR RUJUKAN}

Gie, The Liang. 1996. Filsafat Keindahan. Yogyakarta: Pusat Belajar Ilmu Berguna.

Ibroni, T.O. 1999. Pokok-pokok Antropologi Budaya. Jakarta:Yayasan Obor Indonesia.

Malinowski, Branislaw. 1983. Dinamika Bagi Perubahan Budaya: Satu Penyiasatan Mengenai Perhubungan Ras di Afrika. Dewan bahasa dan Pustaka Kementerian Pelajaran Pelajaran Malaysia: Malaysia.

Purwadarminta, W.J.S. 1976. Kamus Besar Bahasa Indonesia. Jakarta: Departemen Pendidikan dan Kebudayaan.

Sobur, Alex. 2003. Semiotika Komunikasi. Bandug: PT. Remaja Rosdakarya.

Sutrisno, Mudji Sj.Fx. dan Verhaad Sj. Christ. 1993. Estetika Filsafat Keindahan. Yogyakarta: Kanisius.

Storey, John. 2003. Teori Budaya dan Budaya Pop. Yogyakarta: Memetakan Lanskap Konseptual Cultural Studies. 